\title{
"The war goes on behind bars:" The prisoner of war narrative as a building block of the American myth of origination
}

\author{
András Tarnóc
}

I

The accounts written by prisoners of war (POW) belong to the genre of life writing, that is any written text whose subject is one's life. The POW narratives describe one of the crucial components of the American myth of origination, the captivity motif. The American myth of origination promoted among others by John Cotton, John Winthrop, and Cotton Mather focuses on a group of people chosen by God to carry out a divinely inspired mission of settling a new continent and gaining salvation. The realization of the respective goal incurs the cost of the socalled savage war ${ }^{1}$ waged against the natives and the resulting captivity experience.

The purpose of my essay is to explore how the POW narrative contributes to and reflects the American myth of origination. Additional objectives include the examination of the role of memory in the construction of such texts, the identification of the main components of the plot structure and the principal features of the presentation of the self.

The theoretical apparatus of the research includes the works of Robert Doyle, a foremost expert in the field of POW and war studies, and Pierre Nora's model of memory construction. The primary sources to be explored are the narratives of Prescott Tracy from the Civil War, Patrick O'Brien's story of his escape from a German prison camp in 1917, Robert Swartz's narrative of life in a POW camp run by the Wehrmacht in 1944, and the account of James Bond Stockdale, commanding officer of the Navy Air Force shot down during the Vietnam War. The essay at first introduces the historical and legal background of the POW experience and then provides an illustration for the application of the abovementioned theoretical devices.

1 The concept of the savage war advocates the total eradication of the enemy, "root and branch". This type of warfare did not recognize the general rules of fighting and was characteristic of the conflict of settlers and Indians in the colonial period. The notion was advanced by Samuel Nowell's 1678 sermon, titled "Abraham in Arms," and was advocated among others by Theodore Roosevelt and Lyndon B. Johnson in referring to the conquest of the West and the Vietnam War respectively. 


\section{II}

\section{The historical and legal context of the POW experience}

The first POW experience was related to the American Revolution and War of Independence. Ethan Allen's. "A Narrative of the Capture of Ticonderoga and of his Capture and Treatment by the British Written by Himself" (1849) is considered among the first POW narratives. Allen spares no detail in indicting the British for inhumane treatment: "The private soldiers, who were brought to New York, were crowded into churches... The floors were covered with excrements (sic)...The provision dealt out to the prisoners was by no means sufficient for the support of life. It was deficient in quantity, and much more so in quality." (34).

Since the British did not officially recognize the Unites States the captured soldiers were treated as rebels, and received a harsher treatment within the jurisdiction of Britain. Pursuant to the North Act American soldiers captured on land were charged with treason, while those apprehended at sea were accused of piracy. Another tactic or strategy the Americans objected to was the British practice of paroling officers and separating the line soldiers from the ranked corps while forcefully enlisting men into the British Army.

The Civil War saw the first attempts to establish the rules of war, as one of the guidelines prepared by the Union Army was General Order 100 also known as the Instructions for the Government of Armies of the United States in the Field issued by Francis Lieber, a leading member of the Department of War. It stated that "Men who take up arms against one another in public war do not cease on this account to be moral beings, responsible to one another, and to God" (McCracken 14). This was the first time that the captured soldier's conduct was also determined as he was required only to provide his rank, name, service number, and date of birth to the captor (McCracken 20).

World War One was the first international conflict in which the status of a POW was regulated by a system of rules. The 1874 Brussels conference on military law determined the given criteria and the respective findings were confirmed by the 1899 conference at The Hague. The related conference documents and regulations were signed and approved by the representatives of the United States. The doctrine of the capturer's fortunes, that is the military and economic conditions of the detaining enemy emerged as an unwritten rule guiding the treatment of POWs at this time. Accordingly, if the opposing army or nation did not suffer from hardship the captured soldiers were held in relatively good conditions. Conversely, if the detaining army experienced starvation or lack of resources their prisoners could not count on any better treatment either. According to McCracken American 
POWs received average treatment at this time. One of the best known World War One POWs is Eduard Isaacs, the Navy officer, who was captured by the Germans. Nevertheless, he escaped and was able to provide crucial information to American navy intelligence about the position of the German submarine fleet (Edward U. Isaacs, Prisoner of the U-90, 1919).

The Geneva Convention of 1929 was signed by the main belligerents of the Great War, but Japan opted out by referring to the incompatibility of the Convention with the Bushido code. The Convention stipulated the often cited NRSD rule, that is, the captured soldier was not required to disclose any information besides his name, rank, serial number, and date of birth.

During World War Two the conditions of the POW experience depended on the respective front. Soldiers captured on the European front experienced much better treatment than their counterparts at the Pacific. Most World War Two POW accounts were written by officers of the Air Force as captured officers were considered a potentially valuable source of information for the Germans. At the same time the plight of Americans taken as captives at the Pacific theater was much worse. The Japanese military code of Bushido, or "war as a lifestyle" did not tolerate submission to the enemy and POWs regarded as cowards were treated accordingly. Another important feature of the POW experience at the European front was the call for escape. Officers were obliged to attempt escaping as such acts had a military significance since the enemy would allocate substantial forces to capture the escapee thereby limiting the German forces potentially deployable at the battle field.

Doyle points out that during the Civil War 211400 soldiers were taken prisoners in the south and 30200 of them died in captivity, while 26000 Confederate soldiers did not survive in the POW camps out of the total 220000 (17). In World War One 4120 soldiers were captured and 147 of them died. In World War Two approximately 130200 servicemen were captured and 14072 died, and 78773 were listed as MIA. In the Korean War 7140 Americans were taken captive out of those 2701 died. In the Vietnam War 758 soldiers were taken as POW (17-29).

The Korean War (1950-1953) was the conflict that motivated the American military to develop the Code of Conduct (Henceforth: Code). The issuing of the Code also became necessary because according to the American military establishment by the end of World War Two, but especially during the Korean War American soldiers, primarily because of the given enemy violated international conventions, became "prisoners at war" instead of being prisoners of war (McCracken 2). Nevertheless, despite the widespread media images of large numbers of soldiers collapsing emotionally and physically due to the "brain washing" techniques of mostly Chinese captors, only 11 POWs of the "forgotten war" were court martialed for behavior unbecoming a member of the United States military. 
The Code contains six articles and its primary objective is to confirm the identity and commitment of the American soldier to the military during captivity. It also provides action patterns, reaffirms the status of the POW as a continuing member of the armed forces, makes resistance obligatory and highlights the importance of the contemporary military organizational system and culture. The Code provides crucial psychological support as well.

Article One reinforces the identity of the American soldier: "I am an American fighting man. I serve in the forces which guard my country and our way of life. I am prepared to give my life in their defense." Article Two reiterates that the American soldier never surrenders until he has devices available to resist: "I will never surrender of my own free will. If in command, I will never surrender my men while they still have the means to resist." Article Three emphasizes escape as one of the means of potential resistance: "If I am captured, I will continue to resist by all means available. I will make every effort to escape and aid others to escape. I will accept neither parole nor special favors from the enemy." Article Four prescribes a potential action pattern a POW should follow: "If I become a prisoner of war, I will keep faith with my fellow prisoners. I will give no information or take part in any action which might be harmful to my comrades. If I am senior, I will take command. If not, I will obey the lawful orders of those appointed over me and will back them up in every way." Article Five establishes the limits of information that can be provided to the enemy: "When questioned, should I become a prisoner of war, I am bound to give only name, rank, service number, and date of birth. I will evade answering further questions to the utmost of my ability. I will make no oral or written statements disloyal to my country and its allies or harmful to their cause." Article Six basically reinforces the message of Article One: "I will never forget that I am an American fighting man, responsible for my actions, and dedicated to the principles which made my country free. I will trust in my God and in the United States of America (McCracken 20)."

\section{The theoretical background}

Doyle mapped the plot structure of the POW narrative. Accordingly, the POW experience can be described in seven stages: Pre-capture, Capture, Remove, Landscape, Resistance, Release and Lament (297). The Pre-capture segment usually describes the major landmarks or respective references to main events in the author's life. The conditions of Capture generally are not revealed due to the confidentiality required by the military. The means of Removal are detailed similarly to the Indian captivity narrative as it can take place either on foot, or by motorized vehicles of the enemy. After weathering the difficulties of the Capture stage the prisoner 
provides details of the given holding facility. Resistance refers to the "victim's" attitude to captivity, and its main concern, survival. Survival can be achieved either by passive resistance or active defiance. The first one alludes to refusal to cooperate, while the second can include escape. Doyle makes a distinction between high resistance and least resistance. High resistance alludes to escape and least resistance suggests collaboration or turning renegade. Release can take place via international agreement, parole, liberation, or treaty. The Lament stage includes musing about the wasted opportunities of one's life due to captivity.

The expression of the self is also an important aspect of the POW narrative (Doyle 10). The beleaguered self primarily resulting from the trauma of undergoing a military defeat and suffering a culture shock usually appears at the beginning of the experience, at or soon after the time of capture. The fortunate self alludes to an overall positive appreciation of the captivity experience similarly to that of Mary Rowlandson declaring "It is good for me that I have been afflicted" (90). The distanced self implies a figurative removal from the captivity experience, as the protagonist attempts to stay aloft of the suffering. The soldierly self displays behavior meeting the requirements of the Code of Conduct, a model established by the military to follow even in captivity.

The formation and processing of memory are also crucial aspects of the POW narrative. As Nora asserts the act of remembering creates lieux de memoire, or places of memory. Such memory sites "tear moments of history away from the movement of history" (12). All captives are faced with the duty to remember, or blocking "the work of forgetting" (19). Having been captured, the individual is integrated into a shared history, processes his or her own memories in a formal, material, symbolic, and functional sense. In a formal way the narrative belongs to the category of autobiography, materiality is represented by the text itself, symbolically it is part of the myth of origination, while functionally it fulfils the three roles assigned to myth by Zsolt Virágos, namely explanation, justification, and projection. Nora makes three further distinctions concerning archive, duty, and distance memory. Archive memory refers to the actual physical repository of the memory, duty memory is expressed by the POW heeding the call: "An order is given to remember, but the responsibility is mine and it is I who must remember" (15) and distance memory emphasizing discontinuity removes the actual recalled episode from the continuous flow of history. (16). 


\section{Analysis of selected narratives}

Prescott Tracy was held as a POW in Andersonville, Georgia, at one of the most infamous prison compounds of the Confederacy during the Civil War. His time as a POW was relatively brief lasting from June 22, 1864 until August 16, 1864 when he was released as part of an exchange with Southern captives. His report serves a larger purpose, to provide data for the official inquiry carried out by the United States Sanitary Commission. Tracy's Narrative titled Account of Sufferings of Union Prisoners of War of Camp Sumter, Andersonville, Georgia, Private Prescott Tracy on August 16, 1864, is considered a deposition for the compilation of a larger narrative titled Narrative of Privations and Sufferings of United States Officers and Soldiers while Prisoners of War in the Hands of Rebel Authorities by the United States Sanitary Commission (1864).

The narrative can be explored according to Doyle's cyclical model. While his Capture is only briefly described, he provides a rather detailed rendering of the Remove stage including train rides and forced marches to the actual final destination

We were kept at Petersburg two days, at Richmond, Belle Isle, three days, then conveyed by rail to Lynchburg. Marched seventy-five miles to Danville, thence by rail to Andersonville, Georgia. At Petersburg we were treated fairly, being under the guard of old soldiers of an Alabama regiment; at Richmond we came under the authority of the notorious and inhuman Major Turner, and the equally notorious Home Guard [...] Another batch of prisoners joining us, we left Richmond sixteen hundred strong (259).

The capture is clearly marked and he provides appropriate self-identification in fact he gives his name and rank anticipating the NRSD rule of the Code of the American Fighting Man. He also offers a detailed description of his journey to Andersonville. While he does not provide Pre-capture information, the details of his Capture and Remove are rather thorough: "I am a private in the 82nd New York Regiment of Volunteers, Company G. Was captured with about eight hundred Federal troops, in front of Petersburg, on the 22nd of June, 1864" (259). Tracy provides exhaustive information concerning his removal as the waystations to the prison camp are fully listed. The physical and logistical conditions are clearly described as well. Furthermore, the account contains the exact depiction of food rations, a staple of antebellum slave narratives: "Our ration was a pint of beans, four ounces of bread, and three ounces of meat a day" (259).

Tracy also offers a painstakingly detailed depiction of the POW camp holding 28,000 to 35,000 captured soldiers. He describes the dreaded fence or "dead-line," 
through which if the captive extended even a finger, he would be shot. He also discloses the logistical arrangements of the camp:

This prison is an open space, sloping on both sides, originally seventeen acres, now twenty-five acres, in the shape of a parallelogram, without trees or shelter of any kind. The soil is sand over a bottom of clay. The fence is made of upright trunks of trees, about twenty feet high, near the top of which are small platforms, where the guards are stationed (260).

Tracy's entry to the prison camp is also described in an emotionless almost indifferent way, as no references are made to the end of one's freedom or to the ominous sound of a gate slamming shut. Instead of providing a depiction of his mental state Tracy immediately starts to describe the physical surroundings. This of course is one of the best known techniques of coping with the trauma of captivity as turning one's attention outward was often deployed by the captives of Indians. Suffice to mention Mary Rowlandson or Rachel Plummer providing a detailed description of the surrounding landscape in their narrative. Plummer writes that "Notwithstanding my sufferings, I could not but admire the country" (339) and informs the reader about the plant and animal world of the prairie. In the same vein Mary Rowlandson functions as an ethnographer providing information on the dietary habits of her captors (83).

The Landscape section also includes descriptions of the given ordeal. As Tracy reports until the appearance of the Alabama Home Guard and the "notorious and inhuman Major Turner" (259) the POWs were not mistreated. The greatest suffering was caused by starvation or poor nutrition. Tracy provides a detailed account of the substandard hygienic and dietary conditions. He depicts the mental state of his fellow prisoners as: "melancholy, beginning in despondency and tending to a kind of stolid and idiotic indifference" (265). Yet he points out that theft, robbery, even homicide took place among the captives.

The narrative also contains examples of Resistance. One such manifestation could be the actual break through the deadline, "About two a day were thus shot, some being cases of suicide, brought on by mental depression or physical misery, the poor fellows throwing themselves, or madly rushing outside the "line" (265). Another form of resistance is the preservation of physical and mental fitness, and Tracy describes several ways of how this objective was achieved. The main goal was to break the monotony of captivity and to find a productive pastime which included carving, drawing, or any creative activity, which required "long and patient execution" (266). "Many were wise and resolute enough to keep themselves occupied - some in cutting bone and wood ornaments, making their knives out of iron hoops — others in manufacturing ink from the rust from these same hoops, and 
with rude pens sketching or imitating bank notes or any sample." Tracy provides only a succinct rendering of his Release and information concerning any regret or lament cannot be found. Tracy was freed as a result of a prisoner exchange, but he does not present details of that transaction either. The term used by him, "I was exchanged" expresses self-objectification.

As far as the personal aspects or self-presentation of the POWs is concerned, it is noteworthy that the beleaguered self is not discernible in the narrative as Tracy reports in a rather matter of fact way about the capture, even mentions being "treated fairly" during the transfer to Andersonville. The soldierly self is suggested by Tracy's self-definition and his remark concerning the patriotism of his fellow captives. He highlights that despite the suffering many soldiers refused to swear an oath to the Confederacy. "I carry this message from one of my companions to his mother: "My treatment here is killing me, mother, but I die cheerfully for my country" (269). Another manifestation of the soldierly self is the escape attempts as Tracy describes some efforts made by his comrades to flee primarily by digging tunnels. Conversely the detached self, implying an effort of the POW to distance himself from his suffering, appears in his description of the criminal acts committed by his peers. He bitterly points out that "it is a melancholy and mortifying fact, that some of our trials came from our own men. At Belle Isle and Andersonville there were among us a gang of desperate men, ready to prey on their fellows. Not only thefts and robberies, but even murders were committed" (266). The use of the passive voice along with such terms as "melancholy, mortifying fact" suggest Tracy's intention to maintain a distance from his ordeal regardless of the first person plural narration.

The account also shows how the prisoners' living conditions depended on the captors' fortune as the doctor on duty in the camp, Dr. White often expressed his regret that he had had very limited supplies and this prevented him from providing better care for the captives. Tracy describes Captain Wirtz, the commanding officer of the Andersonville POW facility, as "harsh, though not without kindly feelings" (266). In Tracy's case Nora's concept of the duty to remember must be taken literally as he is called upon by the military establishment to share his recollections for the purposes of a court martial inquiry. On the one hand he wants to commemorate his comrades' and his ordeal, but he also responds to an official call, namely the Army Commission investigating the crimes of Captain Wirtz. 
Patrick O'Brien was one of the first Americans to fight in World War One. His captivity similarly to Prescott Tracy's lasted a short time. He was a member of the Royal Canadian Flying Corps as he volunteered to be a fighter pilot before the United States entered the war. After several successful aerial dog-fights his feats became known among the Germans as well, but he was shot down over Belgium. He was injured and taken to a POW camp in Courtrai. After spending three weeks at the camp he was placed on a prisoner train bound for Germany, but he escaped from there. He was hiding in Belgium for 72 days before making it to neutral territory in Holland. He published his recollections with the title Outwitting the Hun: My Escape from a German Prison Camp (1917).

The narrative is not a classic POW account as his experiences as a POW literally ended quite early. Naturally not all aspects of Doyle's cyclical model can be applicable in this case. Regarding his pre-Capture life, we learn that he wanted to prove himself and hoped to "earn his wings." His main motivation to go to war was the desire for adventure: "I was anxious to get into active service and there didn't seem much chance of America ever getting into the war, I resigned and, crossing over to Canada, joined the Royal Flying Corps at Victoria, B. C.” (8). He provides a detailed description of his capture and we learn about the injuries he sustained on that day on August 17, 1917. "A burst of bullets went into the instrument board and blew it to smithereens, another bullet went through my upper lip, came out of the roof of my mouth and lodged in my throat, and the next thing I knew was when I came to in a German hospital the following morning at five o'clock, German time" (33).

Although he points out that ideological considerations did not play a role in his decision to join the war effort, the title of his account reflects the impact of the successful British propaganda depicting Germany as the Huns overrunning innocent Belgium. Naturally, he compares Kaiser Wilhelm to Attila the Hun as well. After capture he is provided medical care and receives a relatively good treatment which is due to two factors, him being known as a famous fighter and as an officer at the same time. The fact that he cannot actually continue his participation in the war as a fighter pilot exacerbates his ordeal: "One of the hardest things I had to endure throughout the two weeks I spent there was the sight of the Hun machines flying over Courtrai, knowing that perhaps I never would have another chance to fly" (58).

Despite the acceptable conditions as his guards even took him to a swimming pool several times, he is dedicated to escaping, a plan he realizes after jumping off the prisoner train heading to Germany. The narrative primarily describes his adventures and emphasizes his survival skills as well. Although the text is not motivated by religious considerations, the author does not omit mentioning divine interference: "Without the help of Providence I would not be here to-day" (xii). 
Following Doyle's taxonomy, the Landscape is also described in considerable detail:

The prison, which had evidently been a civil prison of some kind before the war, was located right in the heart of Courtrai. The first building we approached was large, and in front of the archway, which formed the main entrance, was a sentry box. Here we were challenged by the sentry, who knocked on the door; the guard turned the key in the lock and I was admitted. We passed through the archway and directly into a courtyard, on which faced all of the prison buildings, the windows, of course, being heavily barred (54).

While he offers a depiction of his surroundings as a captured soldier, despite his escape he does not consider himself a free man until he reaches Holland. Just like in the case of escaped slaves he is led by the North Star on his way: "I located my friend, the North Star" (108). Similarly to the plot structure of the slave narrative, O'Brien being "weak, nearly starving to death, a refugee in a hostile country" (99) reaches the emotional and physical low point during his ordeal. His physical condition is like that of the "real" POWs: "actual hunger, and the accompanying worry naturally reduced my weight" (108).

He receives reluctant help mostly from poor Belgian people and eventually reaches the Dutch border and makes his way to freedom by crawling under the electric fence to neutral territory. Upon reaching Allied headquarters, he provides crucial information on military, logistical, and economic issues pertaining to the enemy.

His narrative includes primarily the description of the soldierly self. By his escape he fulfils a duty expected of officers. Despite "hunger pangs gnawing at his insides" (140), he is able to observe the positions of German fighting forces and estimate the extent of the enemy food supply. He views his surroundings from the point of view of a military man and a strategy expert: "When I saw these military roads in Belgium for the first time, with their heavy cobblestones that looked as if they would last for centuries, I realized at once why it was that the Germans had been able to make such a rapid advance into Belgium at the start of the war" (135).

The beleaguered self appears to be irrelevant, primarily due to the favorable treatment he received at the POW camp. As his greatest regret was his inability to fly, his captivity can be interpreted as the manifestations of the fortunate self. The detached self appears during his almost hallucinatory state of mind brought on by starvation and fear. In fact, he carries on a conversation between his brave soldierly and "yellow" self. 
There you are, you old North Star!" I cried, aloud. "You want me to get to Holland, don't you? But this Pat O'Brien-this Pat O'Brien who calls himself a soldier-he's got a yellow streak-North Star-and he says it can't be done! He wants me to quit- to lie down here for the Huns to find me and take me back to Courtrai-after all you've done, North Star, to lead me to liberty. Won't you make this coward leave me, North Star? I don't want to follow him-I just want to follow you-because you-you are taking me away from the Huns and this Pat O'Brien-this fellow who keeps after me all the time and leans on my neck and wants me to lie down-this yellow Pat O'Brien wants me to go back to the Huns! (117)

The narration is a result of duty memory arising from an obligation to himself, to his fellow captives, and to the military establishment. The narrative is dominated by the aspect of the Resistance and its most radical aspect, the escape. In fact, he anticipates the archetypal hero of post-World War Two fiction, the RAF officer "shot down over Europe, captured, imprisoned, then escaping" (Worpole 55). Although he was treated as a hero after his return, and was even received by King George, later he committed suicide due to marital and financial problems. The title of his work, especially the term, "outwitting" is a reminder of the figure of the trickster, a character often used by minority authors. In lieu of economic and military power the trickster has to rely on his wits and O'Brien was often compelled to resort to tricks in order to achieve his freedom.

Robert Swartz was serving as a navigator on a B-17 bomber of the $306^{\text {th }}$ Bomb Group during World War Two. He was taken captive after his aircraft was shot down. His narrative does not provide information related to his capture as it is considered a military secret or confidential information. At the same time, he refers to the episode as a horror story whose details he would like to remove from his memory. Thus in this case the duty memory works in a selective way, as he would put "the machine of forgetting" in motion regarding certain episodes. The refusal to reveal details of his Capture is reminiscent of the authorial strategy of the antebellum slave narrative as the producers of those texts declined to divulge information about their escape in fear of endangering their helpers or their companions left behind.

Similarly to other POW narratives a substantial part is dedicated to the description of the Landscape. As an officer of the Air Force he is transferred to a POW camp located at the Baltic region and run by the Luftwaffe. He reports about the relatively acceptable and proper treatment of the captives. The readers are provided detailed information on the location, the number and size of the 
barracks, the identity of the captives, even the number of the nails in the barbed wire are reported. The observation of the prisoner of war status on the part of the Germans is indicated by the ability of both the British and American Red Cross to forward packages into the camp. Swartz does not mention starving as part of his ordeal, but alluding to the capturers' fortune doctrine he reports on a limited availability of food mostly due to the German rationing efforts in the winter. The author also alludes to certain forms of Resistance. The narrative describes the system or rules the captives had to observe. The Germans continuously monitored the number of the prisoners in order to prevent any escape attempts. At the same time the Americans developed a set of rules too. Although the Code of the American Fighting Man had not yet been issued, in order to avoid any collaboration with the enemy the prisoners followed the "give them nothing but abuse and lofty indifference." principle. Naturally the "lofty indifference" generated behavior is reminiscent of the distanced self. Another example of resistance was the "goonguard," a fellow captive chosen to look out for approaching German guards to search the barracks.

The relatively good treatment of the captives was guaranteed by international laws as the POWs were "furnished with the bare necessities." They were given the opportunity to participate at religious services, to get access to books, even to improve their knowledge by learning. Swartz makes mention of several classes organized among the "kriegies." The captors' fortune doctrine, however, is at play again as by early 1945 the food rations have become smaller and malnutrition or even hunger becomes a daily challenge: "Most of February and March had been grim times. Food had not been plentiful. We were never starving, but we had been mighty hungry at times and all of us lost weight. We had not had a single Red Cross parcel since the $27^{\text {th }}$ of February." The text also describes the need to make up for lost time, or in his case lost meals, as he sends a detailed menu broken down to the various food groups to his parents to prepare for him after his return home:

All during our confinement we were denied many of the things we once thought were the essentials of life. Food was the most important of these and especially during the lean period, we talked of little else. When I first get home I want to make up for lost time. For once in my life I will pay the bills and I want to eat. So you can prepare, here is an idea of what I am looking forward to.

Similarly to the Caribbean slave narratives, the account contains poems and various literary works of his fellow captives. The main theme is loneliness, and longing for the family or loved ones left behind. Despite the fact that religious 
considerations did not primarily motivate the writing of POW narratives, Swartz' account contains details of the mass held in the camp at Easter. The sermon of the chaplain draws a parallel between the Passion of Christ and the ordeal of the captives. In both cases death and resurrection played a dominant role. As Reverend Mitchell pointed out the death of Christ spoke to all and his resurrection was the rebirth of everyone. Swartz along with his fellow captives' experiences "the wonder of resurrection $[. .$.$] in the pulsating life of spring."$

The captivity of Swartz ends on May $1^{\text {st }} 1945$ when American troops take over the camp. The Release despite the momentary euphoria of the prisoners, "everyone rushed outside in a great display of emotion" proves to be anticlimactic as the commander of the Russian troops succeeding the Americans expresses its disapproval upon the lack of sufficient enthusiasm displayed by the former captives "over their liberation."

The Swartz narrative begins with the description of the beleaguered self alluding to the horror of the Capture, but the statement "we refer to these events as 'horror stories' and there is much we would like to forget" conveys a sense of detachment from the respective episodes. Thus the text reveals the dual working of memory. On the one hand, it puts the machine of forgetting into operation by excluding the details of the Capture, on the other it compels the captives to provide the logistical details of their POW experience to their superiors. At the same time the narrative is written in a letter format expressing a more intense, almost live connection with the intended addressee, the parents. The soldierly self is present in the establishment of the internal chain of command and the forms of resistance displayed:

We were forced to abide by the rules of the Germans, but cooperation was unheard of. Whenever a new German order came out it was S.O.P. to ignore it until forced to comply. The motto was 'give them nothing but abuse and lofty indifference.' Within the camp we had our own American organization. Naturally we observed and obeyed all orders from our officers.

Although the Code of the American Fighting Man had not yet been issued, the captives' main concern was to avoid even the faintest likelihood of collaboration with the enemy. The resistance was mostly passive, and the motto implies both distancing from the captors and an effort of the captives to detach themselves from their ordeal.

The narrative of James Bond Stockdale titled Courage under Fire is not only a traditional confinement narrative, but a philosophical essay about life and one's conduct in the face of peril. Stockdale served as the commanding officer of the Navy and he became the highest ranked POW in Vietnam after he was shot down 
on September 9, 1965. He made good use of his studies of philosophy in college as he relied on the teachings of Epictetus, the Stoic during his ordeal. He viewed his captivity at the Hoa Lo prison known as "Hanoi Hilton" as a "laboratory of human behavior" (Courage 1) and was able to hold himself together in the hardest and most difficult circumstances by the help of Epictetus and the Code. Accordingly, he developed a distanced attitude towards his fate. He removed himself from his suffering which included solitary imprisonment for four years, torture, and wearing shackles for extended times. As he warned, one must be indifferent to his status in life as it can change any time.

Stockdale's narrative reflects Doyle's cyclical model. The Pre-Capture stage describes how he finished his education, established a family, and started his military career. Naturally Epictetus' teachings had the greatest impact on him. $\mathrm{He}$ also shared the praise of military life professed by the Romans and he fully subscribed to the view expressed by the motto, "vivere militare." ${ }^{2}$ The Capture stage reveals the conditions of being shot down on September 9, 1965. A he states after being ejected he was transferred from the world of technology to the world of Epictetus. His strengthened resolution or resolved will is shown by the following sentence: "between pulling the ejection handle and coming to rest on the street, I had become a man with a mission" (11). The Removal state also indicates that for Stockdale despite being captured the war continues behind bars.

Stockdale does not assign priority to the description of the Landscape. He dispels the stereotypical view of a POW camp as he points out that the Hanoi Hilton was rather a jail, or "part psychiatric clinic and part reform school" (15). The depiction of the ordeal dominates over that of the given surroundings as the former includes the details of an emotional crisis eventually leading to a suicide attempt. During his tribulations he gains strength from Epictetus, who cautions about excessive insistence on one's status in life while suggesting a more indifferent attitude. Stockdale comes to realize that the greatest loss one can suffer is "destroying the trustworthy, self-respecting, well-behaved man in one" (13)

Being Epictetus' best disciple helps him to develop and implement a form of Resistance, in fact overriding the Code with 'its guilt-inducing echoes of hollow edicts" (15) and developing an action pattern or defense mechanism for all US prisoners to cope with the respective personal, political, and military crisis. The method called BACK US prescribed the following conduct: "Don't Bow in public; stay off the Air; admit no Crimes, never Kiss them goodbye" (15). The second half of the acronym could stand for the United States, but also suggested "Unity over Self," thus reiterating the importance of the community over the individual.

2 Life is that of a soldier's. 
In other words, he underlines the importance of the military community and the inclusion of all his fellow comrades within the chain of command while insisting on the continuing applicability of the martial organization. He not only earned the respect of his fellow captives, but that of the captors as well. After he attempted suicide the Vietnamese were desperately trying to save him since he gained international fame partly due to his wife's televised appeal for humane treatment of POWs.

It is Epictetus' teachings that help him to preserve his soldierly self. Driven by Article Four of the Code, he forges a new chain of command helping his fellow captives to preserve their personal dignity while maintaining aloofness from their captors. The BACK US policy also enables Stockdale and the rank and file to transcend the actual captivity experience and stay away from publicly confessing any alleged crimes committed against the Vietnamese people. The motto, "Unity over Self" expresses that the war goes on behind bars (12) and the chain of command was not broken only transferred from the army barracks and the battle field to the enemy prison camp. While in most POW narratives the beleaguered self appears at the beginning of the given captivity experience, in this case it is manifested in Stockdale's suicide attempt. The narrative also contains traces of the fortunate self as Stockdale considers the POW experience as a path to more effective recognition of the self. He shares Alexander Solzhenitsyn's epiphany upon realizing the value of redemptive suffering: "Bless you, prison, for having been a part of my life" (8).

The term, "laboratory of human behavior" suggests an external look at one's situation. Accordingly, Stockdale functions both as a scientist and the object of inquiry. Although his strong belief system and defense mechanism help him to avoid the beleaguered mental mindset mostly characteristic of the given captivity experience, the suicide attempt indicates the respective psychological and personal nadir.

His experiences are commemorated partly to provide examples to learn from for future generations and also as a manifestation of duty memory, an obligation he owes to the army. The philosophical aspect of his narrative focuses on the applicability of Epictetus' thoughts. In a way his account becomes an example of applied philosophy. The eight year long captivity provides an opportunity to test these ideas. He is able to cope with the trials by insisting on a code of morality. In addition to the Code, he heeds Epictetus's call for preserving one's rectitude outlined by a moral compass. He becomes a Stoic, and this helps him to view his ordeal in an objective way, as he even acknowledges the military prowess and skills of his interrogating officer. "He was a good soldier, never overstepped his line of duty" ("Thoughts") 
The Vietnam War differed from all previous military conflicts the United States became involved in. Not only in its outcome, as it was the only war the country lost, but regarding the psychological pressure the POWs were compelled to endure. Stockdale's narrative thus serves a greater purpose than commemorating one's ordeal for posterity or providing crucial strategic information for the military establishment. His daring stand in adverse circumstances, the very "courage under fire" provides a psychological boost and offers crucial strategic advice for dealing with the inevitable crises of one's life.

\section{III}

The POW narrative testifies not only to the physical and psychological stamina of the captive, but shows how the given ordeal is taken on the personal plane. The POW narrative is the record of the cost the US paid for realizing its national mission underscored by the idea of exceptionalism. The POW experience is also part of the American myth of origination as the protagonist assumes the role of the mythical hero.

The fate of the POW reverberates throughout American history and the narratives project the image of the American hero to the reader. As it was demonstrated these accounts serve multiple audiences, the military establishment and the families left behind or American society in general.

Prescott Tracy displays admirable persistence and an unshakable moral compass along with his commitment to American democracy. Patrick O'Brien provides a notable example of resourcefulness and ingenuity as a successful escapee while Robert Swartz demonstrates how the American soldier can retain self-discipline in adverse conditions. Furthermore, James Bond Stockdale presents an unforgettable illustration of the unbreakable human will.

The POW as the reification of the captivity motif, in itself one of the building blocks of the American myth of origination fulfils the three functions of myth identified by Virágos: explanation, justification, and projection (37). Myths are known to have been able to simplify complex historical and political issues, thereby making them "more palatable" to the average American. Accordingly, the POW narrative and the confinement motif in general can provide a substantiation or easy explanation for the manicheistic interpretation of American history assigning the moral high ground to the United States and relegating the contemporary archenemy into the position of the evil.

Due to the ideological content and the promotion of propagandistic goals the POW narrative carries out a justification function primarily through the emphasis on the cruelty of the enemy. Suffice to point to the horrendous neglect of captive 
militia by the British during the War of Independence, or the tragic disregard of Union soldiers' needs by the Confederate captors, not to mention the physical and psychological brutality of the Vietnamese.

As far as projection is concerned the obligatory moral and physical stand of the captive American soldier is a prerequisite to carrying out the national mission and demonstrating the practical aspects of exceptionalism embraced by John Winthrop in 1630 in his often quoted sermon titled "A Modell of Christian Charity." In fact, the Code of the American Fighting Man contains traces of Winthrop's ideal. The American soldier fighting for a worthy cause, defending the founding principles of the country, refusing to surrender, resisting at all cost and trusting in God sets an example worthy of any resident of this "city upon a hill."

The four texts discussed in this essay testify to the diversity of the POW experience. With the exception of the Civil War narrative the enemy is external, and as it was mentioned earlier, the narratives related to the Vietnam War are associated with military defeat. Although the four accounts originate from different time periods their protagonists project a shared image of the American hero committed to the propagation of the timeless values of democracy, liberty, equality, and individualism. Prescott Tracy's account provides crucial information to the trial of the commander of the infamous Southern military prison. The respective legal proceedings take place at the close of the Crucible of American Democracy, the Civil War. Patrick O'Brien's narrative shows a commitment to individualism, as he achieves his hard earned freedom alone. Robert Swartz became a cog in the machinery of the American military fighting for democracy on the global stage and James Bond Stockdale along with other former captives of the Vietnam War show how individual rectitude can help in turning a military defeat into a moral catharsis.

\section{WORKS CITED}

Doyle, Robert C. Voices from Captivity: Interpreting the American POW Narrative. Lawrence: UP of Kansas, 1994.

McCracken, Harrold J. The Code of Conduct at 42: Time for a Middle-Age CheckUP. J.A.G. 1998.

Nora, Pierre. "Between Memory and History" Representations No. 26 Special Issue: Memory and Counter-memory. (Spring 1989):7-24.

https://doi.org/10.2307/2928520

O'Brien, Patrick. Outwitting the Hun: My Escape from a German Prison Camp. https://www.gutenberg.org/ebooks/42490 Accessed 2019 February 12 
Pattinson, Juliette, Lucy Noakes and Wendy Ugolini. "Incarcerated Masculinities: Male POWs and the Second World War." Journal of War and Culture Studies. 7 (3): 2014. 179-190.

https://doi.org/10.1179/1752627214Z.00000000042

Plummer, Rachel. "A Narrative of the Capture and Subsequent Sufferings of Mrs. Rachel Plummer, Written by Herself." in Held Captive by Indians. Selected Narratives. 1642-1836. Ed. Richard VanDerBeets, Knoxville: U of Tennessee P, 1994. 333-366.

Rowlandson, Mary. "The Sovereignty and Goodness of God." in Held Captive by Indians. Selected Narratives. 1642-1836. Ed. Richard VanDerBeets, Knoxville: U of Tennessee P, 1994. 41-90.

Stockdale, James B. "Courage under Fire: Testing Epictetus's Doctrines in a Laboratory of Human Behavior." http://media.hoover.org/sites/default/files/ documents/978-0-8179-3692-1_1. pdf Accessed 2019 February 21

---. “The Stoic Warrior's Triad: Tranquility, Fearlessness and Freedom.” Lecture, Marine Corps Amphibious Warfare School, Quantico, 18 April 1995, available at www.usna.edu, Accessed 2019 December13

---. Thoughts of a Philosophical Fighter Pilot. Stanford: Hoover Institute Press, 1995.

Swartz, Robert. "Lt. Robert R. Swartz. White Pigeon, Michigan" http://www.merkki.com/swartzrobert.htm Accessed 2019 February 20

Tracy, Prescott. "Deposition of Private Tracy." Narrative of Privations and Sufferings of United States Officers and Soldiers While Prisoners of War in the Hands of the Rebel Authorities. BiblioLife, LLC, 2009. 259-269.

Virágos. Zsolt-Varró Gabriella. Jim Crow örökösei: Mitosz és sztereotípia az amerikai társadalmi tudatban és kultúrában. Budapest: Eötvös József Könyvkiadó, 2002.

Worpole, K. Dockers and Detectives: Popular Reading: Popular Writing. London: Verso, 1983. 